\title{
Artikel
}

\section{Bouwen in een circulaire stad}

\author{
Mr. dr. M.N. (Marlon) Boeve*
}

\section{Inleiding}

Op het terrein van 'bouwen' kunnen belangriike stappen worden gezet om bij te dragen aan de doelstelling om in 2050 volledig circulaire steden te realiseren. In deze bijdrage wordt onderzocht of het huidige en toekomstige omgevingsrechtelijk instrumentarium voldoende mogelijkheden en/of stimulansen biedt om te voldoen aan deze ambitie. ${ }^{1}$ Daarbij worden niet alle mogelijke onderwerpen binnen het thema bouwen in de circulaire stad besproken. ${ }^{2} \mathrm{Na}$ een korte schets van de achtergrond van de problematiek in paragraaf 2 komen de volgende onderwerpen an de orde. Eerst wordt in paragraaf 3 ingegaan op de eisen die aan de circulariteit van bouwwerken kunnen worden gesteld in de ontwerpfase. Besproken wordt in hoeverre de ambities van gemeentelijke 'koplopers' kunnen worden vormgegeven door strenge(re) eisen te stellen an het materiaalgebruik bij nieuwbouw. In paragraaf 4 wordt vervolgens ingegaan op de vraag in hoeverre circulariteit bij bestaande bouw kan worden bereikt. Daarbij gaat het zowel om het plan-

* Mr. dr. M.N. Boeve is als universitair docent verbonden aan het Utrecht Centre for Water, Oceans and Sustainability Law van de Universiteit Utrecht.

1. Het gaat hierbij vooral om het publiekrechtelijk instrumentarium. Voor de privaatrechtelijke aspecten van circulair bouwen kan worden verwezen naar de bijdragen van Chao-Duivis in het Tijdschrift voor Bouwrecht: M.A.B. Chao-Duivis, Privaatrechtelijke aspecten van de circulaire economie in het bijzonder circulair bouwen, TBR 2017/139 en TBR $2017 / 154$

2. Zo besteed ik geen aandacht aan het onderwerp 'van afvalstof naar grondstof', waarbij vooral de reikwijdte van het afvalstoffenbegrip een belangrijk vraagstuk is. Zie hierover o.a. uitgebreid J. Tieman, Afval of grondstof in een circulaire economie - op zoek naar meer rechtszekerheid, in: C. Backes e.a., Met recht naar een circulaire economie (Publicatie van de Vereniging voor Milieurecht 2017-1), Den Haag: Boom juridisch 2017. ologisch instrumentarium om leegstand tegen te gaan, als om de eisen die kunnen worden gesteld aan verantwoord materiaalgebruik bij renovatie. Daarna komen in paragraaf 5 de mogelijkheden in de sloopfase van een bouwwerk aan de orde: in hoeverre kunnen eisen worden gesteld ten aanzien van de scheiding van waardevol bouw- en sloopmateriaal? ${ }^{3}$ De bijdrage wordt in paragraaf 6 afgesloten met een conclusie.

\section{Achtergrond}

De overgang naar een circulaire economie wordt zowel in het Europese als in het nationale beleid gezien als een opgave die essentieel is voor het bereiken van een duurzame, CO2-arme, grondstoffenefficiënte en concurrerende economie. ${ }^{4}$ Ook uit het recente regeerakkoord blijkt dat de circulaire economie hoog op de Nederlandse agenda blijft staan als onderdeel van de klimaatopgave. ${ }^{5}$ Een eenduidige definitie van het concept van de circulaire economie is er niet, maar in de kern gaat het om een systeem dat 'is gericht op het optimaal inzetten en hergebruiken van grondstoffen in de verschillende schakels van de productieketen: van de winning van grondstoffen tot consumptie', aldus een omschrijving van het

3. Met deze indeling in onderwerpen sluit ik, grofweg, aan bij de in dit verband vaak gebruikte 'R-principes': Reduce (slimmer materiaalgebruik), Re-use (een langere levensduur) en Recycle. Zie o.a. Ministerie van len $M$, Beleidsverkenning circulaire economie in de bouw. Een perspectief voor de markt en de overheid, 18 december 2015, p. 22. Soms worden meer R-criteria benoemd (zoals Repair, Refurbish), zie bijv. www.ellenmacarthurfoundation.org/circular-economy/interactivediagram.

4. Zie Mededeling van de Commissie, Maak de cirkel rond. Een EU-actieplan voor de circulaire economie, Brussel, 2 december 2015, COM/ 2015/614 final en het Rijksbreed programma Circulaire Economie 'Nederland circulair in 2050', bijlage bij Kamerstukken II 2015/16, $32852, \mathrm{nr} .33$

5. VVD, CDA, D66 en ChristenUnie, Regeerakkoord 2017-2021 'Vertrouwen in de toekomst', p. 46. 
Planbureau voor de Leefomgeving. ${ }^{6}$ Er wordt gestreefd naar een liefst oneindig hergebruik van grondstoffen, materialen en producten in plaats van deze, zoals in het huidige lineaire systeem, af te danken na (eenmalig) gebruik. ${ }^{7}$ Backes en Tieman wijzen er daarbij op dat de verschillende schakels van de economische kringloop in een circulaire economie niet los van elkaar staan, maar integraal - 'holistisch' - moeten worden bezien. ${ }^{8}$

Ook op stedelijk niveau staat de circulaire economie volop in de aandacht. Amsterdam, Rotterdam, Utrecht en andere steden streven ernaar om in 2050 de transitie te hebben voltooid naar een circulaire economie. Deze ambitie is vastgelegd in een 'City Deal Circulaire Stad', waarin onder meer als doel is geformuleerd om de Nederlandse steden internationaal op de kaart te zetten als 'koplopers' van de circulaire stad. ${ }^{9}$ Daarbij is het onderwerp 'bouwen' een belangrijk thema. Zo volgt uit een studie die ten grondslag lag aan de visie 'Amsterdam circulair' uit 2015 dat de bouwketen een van de twee ketens is waar de grootste impact is te behalen voor de transitie naar een circulaire economie in de stad. ${ }^{10}$ Een goed afgestemde planning van bouwen en slopen waardoor materialen uit gesloopte gebouwen weer kunnen worden hergebruikt in nieuwe of te renoveren gebouwen, multifunctionele gebouwen die wisselend kunnen worden gebruikt zodat ze een langere levensduur hebben, en een 'slimme' sloop waarbij herbruikbare producten en materialen herkenbaar worden gescheiden, het zijn een aantal voorbeelden van circulaire initiatieven in de bouwketen, die worden genoemd in de Amsterdamse visie. ${ }^{11}$ Niet alleen op stedelijk niveau, maar ook op nationaal en Europees niveau wordt overigens de potentie van de bouwsector in het kader van de circulaire economie erkend. In het EU-actieplan voor een circulaire economie is 'bouw en sloop' als een van de prioritaire thema's aangemerkt. De bouw en sloop zijn volgens het EU-actieplan qua volume een van de grootste afvalbronnen in Europa. Veel van dit afval kan worden gerecycled of hergebruikt, maar binnen de EU lopen de percentages op dit punt sterk uiteen. ${ }^{12}$ Ook wordt gewezen op de

6. Zie themasites.pbl.nl/circulaire-economie. De SER hanteert een ruimere omschrijving: 'een economie die binnen ecologische randvoorwaarden efficiënt en maatschappelijk verantwoord omgaat met producten, materialen en hulpbronnen, zodat ook toekomstige generaties toegang tot materiële welvaart behouden', SER, Werken aan een circulaire economie: geen tijd te verliezen, Den Haag 2016, p. 11.

7. Zie ook Raad voor de leefomgeving en infrastructuur, Circulaire economie. Van wens naar uitvoering, juni 2015, p. 7.

8. C. Backes \& J. Tieman, Inleiding, in: C. Backes e.a., Met recht naar een circulaire economie (Publicatie van de Vereniging voor Milieurecht 2017-1), Den Haag: Boom juridisch 2017, p. 9. Zie ook de oratie van C. Backes, Law for a circular economy, Den Haag: Eleven international publishing 2017, p. 13-14

9. Stcrt. 21 februari 2017,9491

10. Amsterdam circulair. Een visie en routekaart voor stad en regio, oktober 2015, p. 13 (beschikbaar via www.amsterdam.nl/bestuur-organisatie/ volg-beleid/agenda-duurzaamheid/publicaties-duurzaam/onderzoekamsterdam/). De andere keten betreft de organische reststroomketen.

11. Amsterdam circulair. Een visie en routekaart voor stad en regio, oktober 2015, p. 17.

12. Technopolis, Regulatory barriers for the Circular Economy. Lessons from ten case studies, final report 13 juli 2016, p. 44. rol die de bouw speelt bij de milieuprestaties van gebouwen tijdens de levensduur daarvan. ${ }^{13}$ In het nationale Rijksbrede programma Circulaire Economie 'Nederland circulair in 2050' wordt de bouw ook als prioriteit gezien. Hoewel het percentage hergebruik van bouw en sloopafval in Nederland hoog is (95\%), wordt een belangrijk deel hiervan op een laagwaardige manier hergebruikt omdat het vooral wordt verwerkt als granulaat voor fundering onder wegen en nieuwbouwwijken. ${ }^{14}$ Door materialen afkomstig van gebouwen als bouwmaterialen voor de woningbouw te gebruiken kan een hoogwaardiger verwerking worden bereikt. In de ontwerpfase zal hier al op moeten worden ingespeeld, bijvoorbeeld door 'modulair' te bouwen, waarbij de afzonderlijke bouwmodules of eenheden kunnen worden hergebruikt. ${ }^{15}$ Een nog verdergaande circulariteit kan worden bereikt als een geheel bouwwerk door renovatie of transformatie kan worden hergebruikt. In het Rijksbrede programma Circulaire Economie 'Nederland circulair in 2050' wordt er dan ook op gewezen dat bij circulair bouwen ook 'de functie van een bouwwerk en zelfs stedelijke ontwikkeling' van belang zijn. ${ }^{16}$ Juist de steden wordt een belangrijke rol toebedeeld bij de overgang naar circulair bouwen. De haalbaarheid van recycling wordt bijvoorbeeld het hoogst geacht in dichtbevolkte en verstedelijkte gebieden vanwege de geografische nabijheid van vraag en aanbod, waardoor de vervoersafstanden korter zijn. ${ }^{17}$

\section{Nieuwbouw: circulair ontwerp en materiaalgebruik}

Bij circulair bouwen is de ontwerpfase van het gebouw een belangrijke fase. Beslissingen over het ontwerp en de keuze voor bouwmaterialen bepalen immers in belangrijke mate het gebruik van hulpbronnen. ${ }^{18}$ Vanuit een oogpunt van circulariteit is het daarbij van belang om te weten welke materialen worden gebruikt in het gebouw, ${ }^{19}$ of ze gemakkelijk kunnen worden ontmanteld en gescheiden, en of ze geschikt zijn voor hoogwaardig hergebruik. ${ }^{20} \mathrm{Op}$ Europees niveau zijn, anders dan ten

13. EU-actieplan voor de circulaire economie, p. 18

14. Rijksbreed programma Circulaire Economie 'Nederland circulair in 2050', p. 60.

15. Ministerie van lenM 2015, p. 22

16. Rijksbreed programma Circulaire Economie 'Nederland circulair in 2050', p. 61.

17. Europese Commissie, EU-protocol bouw- en sloopafvalbeheer, 9 september 2016, p. 27. Zie ook in meer algemene zin Ellen MacArthur Foundation, Cities in the circular economy: An initial exploration, augustus 2017, te raadplegen via www.ellenmacarthurfoundation.org/ publications/cities-in-the-circular-economy-an-initial-exploration. De Ellen MacArthur Foundation is een stichting die als doel heeft de overgang naar een circulaire economie te versnellen.

18. Europese Commissie, Mededeling over mogelijkheden voor hulpbronnen-efficiëntie in de bouwsector, COM/2014/445 final, p. 2.

19. In dit verband wordt wel gesproken van 'materialenpaspoorten'.

20. Backes 2017, p. 47 
aanzien van de energieprestatie van gebouwen, ${ }^{21}$ geen criteria vastgesteld voor de mate van circulariteit van materiaalgebruik in gebouwen. ${ }^{22}$

In Nederland zijn op dit onderwerp wel al verdere stappen gezet.

\subsection{Milieuprestatie (grenswaarde) in Bouwbesluit 2012}

Voor de toetsing van bouwplannen op aspecten als de effecten op het milieu van te gebruiken materialen en energiezuinigheid is het Bouwbesluit 2012 het belangrijkste juridische kader. ${ }^{23}$ In het Bouwbesluit 2012 zijn technische (en andere) voorschriften opgenomen vanuit een oogpunt van veiligheid, gezondheid, bruikbaarheid, energiezuinigheid of milieu. ${ }^{24}$ De voorschriften geven de minimale eisen waaraan een bouwplan moet voldoen. In het Bouwbesluit 2012 zijn specifieke voorschriften opgenomen voor de milieuprestaties van het materiaalgebruik bij de nieuwbouw van woningen en de nieuwbouw van kantoren groter dan $100 \mathrm{~m} 2$. Deze voorschriften hebben als doel het duurzaamheidsgehalte van deze bouwwerken te verhogen. ${ }^{25}$ Het zijn vooralsnog echter voorschriften met een weinig dwingende uitkomst; enkel is in art. 5.8 van het Bouwbesluit 2012 bepaald dat het te bouwen bouwwerk zodanig is dat de belasting van het milieu door de in het bouwwerk toe te passen materialen wordt beperkt, waarbij in art. 5.9 een specifieke te hanteren berekeningssystematiek - de Bepalingsmethode Milieuprestatie Gebouwen en GWW-werken - is voorgeschreven. ${ }^{26}$ Overlegt de aanvrager van een omgevingsvergunning voor bouwen de berekening, dan wordt voldaan aan deze vereisten; de hoogte van de milieuprestaties kan het bevoegd gezag niet afdwingen bij de beoordeling van de aanvraag om een omgevingsvergunning voor bouwen. Ook in de nota van toelichting bij het Bouwbesluit 2012 wordt benadrukt dat een weigering van de omgevingsvergunning voor bouwen niet mogelijk is om redenen van het duurzaamheidsgehalte van het bouwwerk. Optimistisch wordt daarbij opgemerkt:

'Het staat het bevoegd gezag uiteraard vrij om in zo'n geval een gesprek met de aanvrager van de omgevingsvergunning aan te gaan teneinde hem van de wenselijkheid van een hoger duurzaamheidsniveau te overtuigen. ${ }^{27}$

Inmiddels is een ontwerpbesluit tot wijziging van het Bouwbesluit 2012 naar de Tweede Kamer gestuurd waarin een zogenoemde milieuprestatiegrenswaarde is

21. Zie Richtlijn 2010/31/EU van het Europees Parlement en de Raad van 19 mei 2010 betreffende de energieprestaties van gebouwen.

22. De EU lijkt op dit punt ook geen verdere actie te ondernemen, zie Backes 2017, p. 47

23. Het Bouwbesluit 2012 is van toepassing bij zowel vergunningplichtige als niet-vergunningplichtige bouwwerken (zie art. 2.10 Wabo en art. 1b lid 1 Woningwet).

24. Art. 2 Woningwet.

25. NvT bij Bouwbesluit 2012, Stb. 2011, 416, p. 296

26. Art. 5.8 en 5.9 Bouwbesluit 2012.

27. NvT bij Bouwbesluit 2012, Stb. 2011, 416, p. 297. opgenomen. ${ }^{28}$ Het betreft een milieuprestatiegrenswaarde voor woningen van ten hoogste 1 volgens de eerdergenoemde Bepalingsmethode Milieuprestatie. Voor kantoren groter dan $100 \mathrm{~m} 2$ gaat eenzelfde grenswaarde gelden. ${ }^{29}$ Hiermee wordt dus een daadwerkelijke eis aan de milieuprestaties van de toe te passen materialen in bouwwerken gesteld. Om te voldoen aan deze grenswaarde wordt de milieuprestatie van het gehele bouwwerk berekend op basis van de milieuprestaties van de verschillende producten en onderdelen waaruit een bouwwerk bestaat. Daarbij wordt uitgegaan van de zogenoemde levenscyclusanalyse, waarbij alle fasen in de levensloop - zoals productie, constructie, recycling, hergebruik en afdanking - van een product worden meegenomen. ${ }^{30}$ De methode schrijft geen materialen en producten voor, het is aan de aanvrager om de keuzes te maken bij het ontwerp, het materiaalgebruik en de constructie van het bouwwerk om uiteindelijk te kunnen voldoen aan de grenswaarde.

Of de beoogde milieuprestatiegrenswaarde erg ambitieus is, is de vraag. ${ }^{31}$ Volgens de nota van toelichting bij het ontwerpbesluit kan in ieder geval het merendeel van de nieuw te bouwen woningen aan deze grenswaarde voldoen. ${ }^{32}$ Ook in een rapport van SIRA Consulting over de effecten van de wijziging van het Bouwbesluit 2012 op dit punt wordt erop gewezen dat de norm zo is gekozen dat de huidige gangbare bouw hieraan voldoet. De wijziging levert dan ook geen verhoging van de administratieve lasten of nalevingskosten op. ${ }^{33}$ Hier lijkt al met al weinig stimulans van uit te gaan. Over een evaluatie om te bezien of met deze norm aan de ambities met betrekking tot duurzaamheid en circulariteit wordt voldaan en verdergaande aanscherping wordt niet gerept in de nota van toelichting bij het ontwerpbesluit tot wijziging van het Bouwbesluit 2012.

\subsection{Hogere ambities?}

Er staat een initiatiefnemer niets in de weg om vrijwillig verdergaande maatregelen dan de eisen van het Bouwbesluit 2012 ten aanzien van de milieueffecten van het materiaalgebruik toe te passen. Verdergaande maatrege-

28. Bijlage bij Kamerstukken II 2016/17, 32 757, nr. 141. De beoogde datum van inwerkingtreding is 1 januari 2018.

29. Bij 'kantoren' gaat het overigens alleen om zelfstandige kantoren (al dan niet onderdeel van een groter kantoorgebouw). Voor zover een kantoor een nevenfunctie is van een andere functie, denk aan een kantoor bij een ziekenhuis of school, dan is geen sprake van een kantoorgebouw in de zin van het Bouwbesluit 2012. En ook wanneer een 'kantoor' onderdeel uitmaakt van een gebouw met andere functies, zoals winkels, horeca, enz. (een combinatiegebouw), geldt de milieuprestatiegrenswaarde niet, zie art. 1.1 lid 3 en 5.9 lid 4 ontwerpbesluit tot wijziging Bouwbesluit 2012 en p. 12 NvT, Bijlage bij Kamerstukken II 2016/17, 32 757, nr. 141.

30. W/E adviseurs, Principes en parameters Milieuprestaties Gebouwen (MPG). Eindrapport, Utrecht 24 februari 2017, p. 14-15 (te raadplegen via www.milieudatabase.nl/imgcms//Eindrapport\%20Onderzoek \%20principes\%20en\%20parameters\%20MPG\%2024-02-2017.pdf).

31. Kritisch op dit punt: Backes 2017, p. 51.

32. NvT bij het ontwerpbesluit tot wijziging van het Bouwbesluit 2012, p. 11.

33. SIRA Consulting, Effectmeting wijziging Bouwbesluit 2012. Drijvende bouwwerken, milieuprestatiegrenswaarden en de label C-plicht voor kantoren, 22 mei 2017, p. 11. 
len kunnen echter vanwege het uitputtende karakter van het Bouwbesluit 2012 niet door het bevoegd gezag worden afgedwongen door regels op te nemen in een bestemmingsplan of in een ander ruimtelijk besluit. ${ }^{34}$ Dit zou alleen mogelijk zijn voor zover een aspect niet uitputtend is geregeld in het Bouwbesluit 2012. Voor zover dit de milieueffecten van het materiaalgebruik betreft lijkt hier dan ook weinig ruimte voor. Het is overigens vaste jurisprudentie dat uitvoeringsaspecten, zoals de mijze van (duurzaam) bouwen, ruimtelijke relevantie missen en daarom niet in het bestemmingsplan kunnen worden geregeld. ${ }^{35}$ De regels in het bestemmingsplan mogen immers op grond van art. 3.1 van de Wet ruimtelijke ordening (Wro) enkel worden gesteld met het oog op 'een goede ruimtelijke ordening'.

Ook het privaatrechtelijke spoor biedt geen soelaas voor het afdwingen van verdergaande maatregelen. Art. 122 Woningwet bepaalt expliciet dat de gemeente geen rechtshandelingen naar burgerlijk recht kan verrichten ten aanzien van de onderwerpen die in of krachtens het Bouwbesluit 2012 zijn geregeld. ${ }^{36}$ Jurisprudentie laat zien dat bijvoorbeeld over het onderwerp energiezuinigheid van woningen geen privaatrechtelijke afspraak mag worden gemaakt, omdat hierover al een regeling is opgenomen in het Bouwbesluit 2012. ${ }^{37}$ Wanneer overigens vrijwillig afspraken worden gemaakt, geldt het verbod van art. 122 Woningwet niet. ${ }^{38}$ Eerder is wel betoogd om art. 122 Woningwet buiten toepassing te verklaren voor zover het de eisen over energiezuinigheid en milieu betreft. ${ }^{39}$ Koeman betwijfelde of met het opheffen van het verbod van art. 122 Woningwet belangrijke stappen in de richting van duurzaam bouwen worden gezet. Daarbij wees hij onder meer op het feit dat er veel nieuwbouwplannen zijn waarover geen privaatrechtelijke afspraken worden gemaakt en art. 122 Woningwet dan ook geen rol speelt, en op de mogelijkheid tot aanscherping van de norm voor energiezuinig bouwen in het Bouwbesluit. ${ }^{40}$ Ook voor de overgang naar circulair bouwen is mijns inziens de vraag gerechtvaardigd of de oplossing gezocht zal moeten worden in individuele

34. Zie bijv. ABRvS 8 maart 2017, ECLI:NL:RVS:2017:600 en ABRvS 22 april 2015, ECLI:NL:RVS:2015:1290.

35. ABRvS 20 februari 2013 ECLI:NL:RVS:2013:BZ1678.

36. Met deze bepaling wordt beoogd te voorkomen dat gemeenten gebruik maken van hun monopoliepositie bij de gronduitgifte en door het stellen van aanvullende eisen de beoogde deregulering en uniformering van het Bouwbesluit tenietdoen, zie Kamerstukken II 2000/01, 27 581, nr. 3, p. 6

37. Rb. Arnhem 7 april 2010, ECLI:NL:RBARN:2010:BM0509.

38. Kamerstukken II 2000/01, 27 581, nr. 3, p. 6, V.H.M. van Os, Duurzaam bouwen in de praktijk. Creatieve alternatieven voor juridische beperkingen, TBR 2014/4, par. 4 en 5.

39. M.Y.C.L. de Wit, Duurzaamheidseisen bij (projectontwikkel)overeenkomsten, TO 2010, afl. 4, p. 129-132.

40. Deze norm voor energiezuinigheid betreft de zogenoemde energieprestatiecoëfficiënt in afd. 5.1 Bouwbesluit 2012. De discussie richtte zich overigens op de energiezuinigheid, niet zozeer op de milieuprestaties van bouwwerken, zie N.S.J. Koeman, Duurzaam ruimtegebruik, bouwen en wonen, TO 2010, afl. 4, p. 156-157. afspraken, en of niet meer winst is te behalen in het voorzien in een duidelijke en ambitieuze norm. ${ }^{41}$

Hierbij moet worden opgemerkt dat de Woningwet mogelijkheden biedt om in uitzonderingsgevallen aanvullende eisen bij nieuwbouw te stellen. Zo biedt art. 120a Woningwet een grondslag om bij AMvB bij wijze van experiment tijdelijk van bij of krachtens $A M v B$ gegeven voorschriften af te wijken of een zodanige afwijking toe te staan. Thans is overigens geen AMvB gebaseerd op deze bepaling. ${ }^{42}$ Ook kan de minister op basis van art. 7a Woningwet (duurzaam bouwen) in een bijzonder geval het bevoegd gezag toestaan om uit het oogpunt van milieu nadere technische voorschriften op te leggen waarin het Bouwbesluit 2012 niet voorziet. Gelet op de voorwaarden die zijn gesteld in de 'Beleidsregels voor de uitvoering van artikel $7 \mathrm{a}$ van de Woningwet ${ }^{\prime 3}$ voor het verkrijgen van een dergelijke toestemming, moet het gaan om experimentele duurzame bouwprojecten. Naast de Woningwet biedt de Crisis- en herstelwet (Chw) de mogelijkheid om af te wijken van de vereisten van het Bouwbesluit 2012 ten behoeve van innovatieve projecten. Daartoe moet een project wel bij AMvB worden aangewezen, waarbij moet worden aangegeven welke afwijkingen zijn toegestaan en de ten hoogste toegestane tijdsduur (art. 2.4 Chw). De resultaten zijn tot nu toe nogal mager, zo blijkt uit de Voortgangsrapportage Crisis- en herstelwet 2015-2016. In totaal zijn zes experimenten voor duurzaam bouwen aangewezen, waarvan er slechts één succesvol in uitvoering is. De andere experimenten zijn gestopt - waaronder de ontwikkeling van een Eco-iglo en een autarkische woning - vanwege het feit dat er 'geen sluitende businesscase' is ontstaan, hoewel de technische ontwikkeling wel was geslaagd. ${ }^{44}$ Deze verschillende wettelijke voorzieningen hebben alle betrekking op experimenten in individuele gevallen en bieden geen mogelijkheid om een algemeen beleid met verdergaande ambities voor circulair bouwen vorm te geven. In die zin bieden deze mogelijkheden slechts weinig stimulans voor de overgang naar circulair bouwen in algemene zin.

\subsection{Bepalingsmethode milieuprestatie circulair?}

Een minder juridische, maar niet onbelangrijke vraag in het licht van het bovenstaande is in hoeverre 'circulariteit' al (voldoende) wordt meegenomen bij het bepalen van de 'milieuprestaties' zoals bedoeld in art. 5.8 en 5.9 van het Bouwbesluit 2012. Uit art. 5.9 van het Bouwbesluit 2012 valt op te maken dat bij de invulling van het begrip 'milieuprestaties' de nadruk ligt op de uitstoot

41. Zie ook P. Mul, S. Roos \& J.B. Jutte, Opportunities and barriers for circular procurement in the built environment, Royal Haskoning, juli 2016, p. 9 (te raadplegen via www.globe-eu.org/wp-content/uploads/GlobeBEE-Paper_circular-procurement-built-environment.pdf).

42. Tot januari 2016 was op basis van deze bepaling het 'Experimentenbesluit excellente gebieden' in werking, Stb. 2010, 288. Dit besluit maakte het mogelijk om in bepaalde aangewezen gebieden vooruit te lopen op de aanscherping van de energieprestatiecoëfficiënt. Het besluit is inmiddels ingetrokken.

43. Stcrt. 1999, 26.

44. Ministerie van lenM, Praktijkervaringen Crisis- en herstelwet. Voortgangsrapportage 2015-2016, Den Haag 2016, p. 19. 
van broeikasgassen en de uitputting van grondstoffen. In een rapport van het RIVM van oktober 2017 wordt geconcludeerd dat de huidige voorgeschreven Bepalingsmethode Milieuprestatie Gebouwen en GWWwerken nog onvoldoende geschikt is om circulaire ontwerpstrategieën in de bouw te realiseren. ${ }^{45}$ Zo blijkt in de methode aandacht te ontbreken voor onzekere factoren, zoals de onzekerheid of de voordelen van nieuwe technieken wel kunnen worden benut. Hoe vaak kan bijvoorbeeld een 'bouwmodule' bij modulair bouwen technisch gezien mee en is er in de toekomst wel een markt voor het hergebruik van de module? ${ }^{46}$ Dergelijke factoren zouden medebepalend dienen te zijn voor het bepalen van de milieuprestaties van een bouwwerk. Mij lijkt het van groot belang dat de methode verder wordt ontwikkeld en geschikt wordt voor het bepalen van de circulaire bouwprestaties. Ook de Europese Commissie heeft het probleem van een gebrek aan betrouwbare en vergelijkbare methoden onderkend. ${ }^{47}$ In het EU-actieplan voor een circulaire economie kondigt de Europese Commissie aan dat er indicatoren zullen worden ontwikkeld voor de beoordeling van de milieuprestaties gedurende de levenscyclus van een gebouw. ${ }^{48}$ In het genoemde rapport van het RIVM wordt ook gewezen op de ontwikkeling van deze Europese methoden en aanbevolen daar zo nodig bij aan te sluiten. ${ }^{49}$

\subsection{Omgevingswet}

In de toekomst is er onder de Omgevingswet meer ruimte voor gemeenten om ten aanzien van de milieuprestatie van nieuw te bouwen woningen en kantoren strengere grenswaarden te stellen, althans uitgaande van het conceptontwerp-Besluit bouwwerken leefomgeving (verder: $\mathrm{Bbl}) .{ }^{50}$ In het $\mathrm{Bbl}$ is net als in de beoogde wijziging van het Bouwbesluit 2012 een milieuprestatiegrenswaarde van ten hoogste 1 opgenomen (art. 4.158 en $4.159 \mathrm{Bbl}$ ). Anders dan het huidige recht staat het $\mathrm{Bbl}$ toe dat op gemeentelijk niveau een strengere waarde wordt gesteld dan deze grenswaarde. In art. $4.160 \mathrm{Bbl}$ is hiertoe bepaald dat met een maatwerkregel gebieden kunnen worden aangewezen 'waarin de volgens de Bepalingsmethode Milieuprestatie Gebouwen en GWW-werken bepaalde milieuprestatie, bedoeld in art. 4.159, voor een woonfunctie of kantoorgebouw wordt aangescherpt'. Maatwerkregels kunnen op grond van art. 4.6, tweede lid, van de Omgevingswet worden gesteld in het omgevingsplan, de omgevingsverordening of de waterschapsverordening, voor zover dit is toegestaan bij AMvB. In het $\mathrm{Bbl}$ is ervoor gekozen om het alleen mogelijk te maken om bij het omgevingsplan maatwerkregels te stellen over de aangewezen onderwer-

45. E. de Valk \& J. Quik, Eenduidig bepalen van circulariteit in de bouwsector. Milieuprestaties als uitgangspunt, RIVM Briefrapport 2017-0128, 20 oktober 2017 (te raadplegen via www.rivm.nl), p. 5.

46. De Valk \& Quik 2017, p. 28

47. Europese Commissie, Mededeling over mogelijkheden voor hulpbronnen-efficiëntie in de bouwsector, COM/2014/445 final, p. 2.

48. EU-actieplan, p. 18

49. De Valk \& Quik 2017, p. 33.

50. Concept van het ontwerpbesluit bouwwerken leefomgeving van 30 juni 2017, te raadplegen via www.omgevingswetportaal.nl. pen. ${ }^{51}$ Het omgevingsplan heeft uitdrukkelijk een ruimere reikwijdte dan het huidige bestemmingsplan, in het omgevingsplan dienen immers regels over 'de fysieke leefomgeving' te worden opgenomen. ${ }^{52}$ Ook regels over de te stellen milieuprestatie-eisen bij bouwmaterialen passen binnen dit criterium. Voor gemeentelijke 'koplopers' biedt het stellen van maatwerkregels over dit onderwerp de mogelijkheid om verdergaande ambities vorm te geven. Een aantal punten valt hierbij wel op. De gemeenteraad zal moeten motiveren waarom voor een specifiek gebied een aangescherpte milieugrenswaarde wordt gesteld in het omgevingsplan. In de gemeentelijke structuurvisie kan bijvoorbeeld beleid op dit punt worden geformuleerd. Hierbij is mijns inziens een aandachtspunt dat het niet gaat om locatiespecifieke regels, de regels kennen geen ruimtelijke relevantie. ${ }^{53}$ Waarom zou het ene deel van een gemeente dan aan een strengere eis moeten voldoen, terwijl deze eis voor een ander deel van de gemeente niet geldt? Voor zover de aangescherpte milieuprestatiegrenswaarde voor het gehele gemeentelijke grondgebied gaat gelden, is dit probleem niet aan de orde. Ook voor wellicht een nieuwe ecowijk, waar de milieuambities hoog zijn, is een aangescherpte grenswaarde voorstelbaar, maar in andere gevallen lijkt het opnemen van een dergelijke maatregel voor een bepaald gebied nog niet eenvoudig te motiveren. Daar komt bij dat tegen de (maatwerk)regels in het omgevingsplan rechtsbescherming openstaat. Belanghebbenden kunnen derhalve opkomen tegen de aangescherpte grenswaarde of juist verzoeken om het stellen van een maatwerkregel.

Ook de Omgevingswet biedt overigens de mogelijkheid om bij wijze van experiment van de bepalingen van het $\mathrm{Bbl}$ af te wijken (art. 23.3 Omgevingswet). Daarbij moet het gaan om bij AMvB aangewezen experimenten die gericht zijn op het voldoen aan de beschermingsdoelstelling van de Omgevingswet, ${ }^{54}$ waaronder de verbetering van de kwaliteit van de fysieke leefomgeving. ${ }^{55}$ Ten aanzien van de milieuprestaties van materiaalgebruik in woningen en (grote) kantoren is al in de mogelijkheid van aanscherping bij maatwerkregel in het omgevingsplan voorzien. Mogelijk dat een toepassing van deze bepaling aan de orde kan zijn voor het stellen van verdergaande technische eisen ten aanzien van bijvoorbeeld modulair bouwen of andere technische eisen. Het Bbl staat immers in de weg aan het stellen van afwijkende technische voorschriften, aangezien het besluit, net als het Bouwbesluit 2012, geacht wordt uitputtend te zijn.

51. Art. 2.3 Bbl. Als reden wordt gegeven dat de regels in het $\mathrm{Bbl}$ zien op onderwerpen waarbij er geen taken of bevoegdheden voor de provincie en het waterschap zijn, NvT bij Bbl, p. 29.

52. Art. 2.4 Omgevingswet.

53. In de NvT bij het Bbl wordt op p. 29 ook opgemerkt: 'maatwerkregels hebben in het algemeen vooral nut bij onderwerpen met een gebiedsgerichte component'. De mogelijkheid om maatwerkregels te stellen over de milieuprestatiegrenswaarde is hierop dus een uitzondering.

54. Zoals opgenomen in art. 1.3, onder a, Omgevingswet.

55. Zie art. 23.3, tweede lid, Omgevingswet en ook Kamerstukken II 2014/15, 33 962, nr. 12, p. 116. Als voorbeeld wordt o.a. genoemd een woningbouwproject waaraan, bij wijze van experiment, extra isolatie-eisen worden gesteld in afwijking van de daarvoor geldende regelgeving, Kamerstukken II 2013/14, 33 962, nr. 3, p. 260. 
De wetgever heeft er dus voor gekozen om een meer ambitieuze normstelling over te laten aan het lokale bevoegd gezag. Hoewel dit past in het uitgangspunt van decentralisatie dat ten grondslag ligt aan de Omgevingswet, is op deze keuze wel iets af te dingen. Juist omdat de milieuprestaties van gebouwen geen locatieafhankelijk aspect kennen, ligt het meer voor de hand dat op nationaal niveau - of beter nog: Europees niveau - een ambitieuze norm voor circulariteit van gebouwen wordt gesteld. Ten aanzien van dat laatste heeft Backes er al op gewezen dat er kansen zijn voor een Europeesrechtelijke aanpak, bijvoorbeeld door aan te sluiten bij de energieprestatienorm in de richtlijn voor de energieprestatie van gebouwen. ${ }^{56}$ Deze aansluiting ligt ook voor de hand, gelet op de relatie tussen deze twee terreinen. Zo blijkt uit onderzoek dat een aanscherping van de energieprestatiecoëfficiënt kan leiden tot een slechtere milieuprestatie, omdat andere en/of extra materialen zullen moeten worden toegepast om de nieuwe waarde te behalen. ${ }^{57}$ Dit vraagt om een samenhangende benadering tussen de normering voor de energieprestaties en de milieuprestaties. Dit neemt niet weg dat de mogelijkheid voor verdergaande lokale ambities wel een goede eerste stap is, zeker in vergelijking met het huidige recht.

\section{Bestaande bouw: renovatie en transformatie}

4.1 Hergebruik gebouwen: voorkomen leegstand Circulair bouwen in de stad gaat niet alleen over de milieuprestaties van nieuw te bouwen gebouwen. Hoe kan circulariteit worden bereikt bij de bestaande voorraad? Indien een bestaand gebouw door renovatie of transformatie kan worden hergebruikt en daarmee een lange(re) levensduur krijgt, past dit in beginsel binnen het systeem van de circulaire economie. ${ }^{58} \mathrm{Zo}$ wordt het oplossen van leegstand ook gezien als onderdeel van de circulaire economie. ${ }^{59}$ Ten aanzien van de mogelijkheden van het planologisch instrumentarium voor het oplossen van de leegstandproblematiek verwijs ik graag naar de bijdragen die reeds zijn verschenen over dit onderwerp. ${ }^{60}$ Wel wil ik nog enige aandacht besteden aan het concept van het 'functieloze' of 'onbestemde'

56. Richtlijn 2010/31/EU van het Europees Parlement en de Raad van 19 mei 2010 betreffende de energieprestatie van gebouwen. Zie Backes 2017, p. 49.

57. W/E adviseurs, Onderzoek 'Bepaling kwaliteitsniveaus milieuprestatie van woonfuncties'. Eindrapport, 14 november 2014, p. 29-30.

58. Wel is er discussie over de vraag of de bouw circulair moet worden door bij leegstand te herbestemmen, of dat het beter is om te slopen en circulaire en duurzame nieuwe gebieden te creëren. Een eenduidig antwoord lijkt (nog) niet te geven, Ministerie van lenM 2015, p. 41.

59. Ministerie van lenM 2015, p. 41

60. Zie o.a. D.B. Stadig \& E.A. Minderhoud, Herbestemming, regelgeving en gemeente (2), TBR 2014/180, M.A. Wintgens \& J.J. Hoekstra, Een verkenning van de mogelijkheden om leegstand van kantoren te bestrijden, anno 2011, TBR 2011/95, H.J. de Vries, De vernieuwende aanpak van de kantorenleegstand door de provincie Utrecht, TO 2015, afl. 3, p. 113-132 en F.A.G. Groothuijse \& D. Korsse, Kanttekeningen bij de Utrechtse kantorenaanpak, TO 2016, afl. 1/2, p. 45-50. gebouw en het onderwerp globaal bestemmen onder de Omgevingswet.

In Amsterdam werd enige jaren geleden het concept van het 'functieloze' gebouw geïntroduceerd. ${ }^{61}$ Het pand zou naar inzicht van de huurders/eigenaren zelf zijn in te delen; allerlei verschillende functies zouden in het gebouw moeten kunnen worden gerealiseerd. De idee was dat een dergelijk gebouw een lange levensduur zou hebben (zo'n tweehonderd jaar) door zorgvuldig materiaalgebruik en de vrijheid bij de indeelbaarheid en functieverandering, waarmee ook leegstand zou kunnen worden voorkomen. Dit concept past in beginsel in een circulaire economie. Zo blijkt ook uit een onderzoek van de ING over circulair bouwen dat het voor investeerders van meerwaarde kan zijn dat de functie van een gebouw eenvoudig en zonder te veel kosten kan worden veranderd. ${ }^{62}$ Een geheel 'bestemmingsvrije' regeling in het bestemmingsplan is evenwel juridisch niet houdbaar. Op zijn minst is het immers de vraag of de mogelijkheid tot vestiging in het gebouw van potentieel conflicterende functies (zowel binnen het gebouw als met functies in de omgeving) zonder beperkingen aanvaardbaar zou zijn vanuit een oogpunt van een goede ruimtelijke ordening en rechtszekerheid. De vervolgvraag is bij een dergelijk concept immers het lastigst, ook in de tijd: kan na het realiseren van de ene functie in het gebouw de realisering van een andere conflicterende functie worden toegestaan? Een ruime bestemmingsplanregeling, bijvoorbeeld 'gemengde doeleinden', is wel aanvaardbaar, maar dit is niet een innovatief concept, veel bestemmingsplannen kennen dergelijke ruime bestemmingsomschrijvingen. Ook moet worden bedacht dat bij een ruime of globale bestemmingsplanregeling de onderzoekslasten hoog kunnen zijn. Bij de beoordeling van de aanvaardbaarheid van de bestemmingsplanregeling moet immers worden uitgegaan van de maximale planologische invulling van het plan. Onder de Omgevingswet zijn de flexibiliteit van het omgevingsplan en het terugbrengen van de onderzoekslasten overigens belangrijke aandachtspunten. Het is de bedoeling dat de regels in het omgevingsplan meer open normen bevatten, die het bouwen en gebruiken minder gedetailleerd vastleggen. ${ }^{63}$ Hiermee wordt beoogd een scheiding te faciliteren tussen de vraag of een functie mogelijk is op een locatie en de vraag onder welke voorwaarden een functie kan worden gerealiseerd. ${ }^{64}$ Deze beoogde fasering blijkt uitdrukkelijk uit de toelichting bij de Omgevingswet, het nieuwe stelsel bevat hiertoe echter geen specifieke bepalingen. Of deze beoogde flexibiliteit van het omgevingsplan en beperking van de onderzoekslasten zo gaan uitwerken

61. Op IJburg onder de benaming 'solids', zie www.inbo.com/nl/projecten/ solids-i-ijburg-amsterdam.

62. ING, Circulair construction. Most opportunities for demolishers and wholesalers (te raadplegen via think.ing.com/reports/circular-construction), p. 10. In het rapport wordt er wel op gewezen dat de relatieve korte investeringstermijn van veel investeerders en de weinige waardering hiervoor nog een obstakel vormen (voor de toegevoegde waarde).

63. Kamerstukken II 2014/15, 33 962, nr. 23, p. 53.

64. O.a. Kamerstukken II 2014/15, 33 962, nr. 12, p. 220. 
als beoogd, is echter de vraag. ${ }^{65}$ Dit zal mede afhangen van de vraag hoe de rechter dergelijke globale plannen, waarbij het moment van onderzoek naar een later tijdstip wordt geschoven, zal beoordelen. Vanuit een oogpunt van rechtszekerheid zal het plan een zekere mate van duidelijkheid moeten bieden om de aanvaardbaarheid van het plan te kunnen beoordelen. Daarbij zal naar verwachting van belang zijn of er nog sprake is van een nader afwegingsmoment, bijvoorbeeld een vergunningplicht, zodat kan worden beoordeeld of het concrete initiatief binnen de randvoorwaarden van het globale plan past. $^{66}$

Het experiment met de functieloze gebouwen in Amsterdam blijkt overigens mislukt. De variatie aan functies kwam maar weinig van de grond en voor zover dit wel lukte, waarbij in een pand zowel woningen als meerdere hotels werden gerealiseerd, leidde dit in de praktijk tot overlast en ontevreden bewoners. ${ }^{67}$

\subsection{Bestaande bouw: eisen milieuprestatie van materiaalgebruik bij renovatie?}

Renovatie van leegstaande gebouwen, zodat ze weer geschikt worden voor hergebruik, past dus binnen circulair bouwen. In hoeverre kunnen bij renovatie ook eisen worden gesteld aan de milieuprestatie van de toe te passen materialen? Art. 5.10 Bouwbesluit 2012 bepaalt expliciet dat de berekening van de milieuprestatie volgens de Bepalingsmethode Milieuprestatie niet van toepassing is 'op het geheel of gedeeltelijk vernieuwen of veranderen of het vergroten van een bouwwerk'. ${ }^{68} \mathrm{Bij}$ de verbouw van bouwwerken worden er dus geen eisen gesteld aan de milieuprestatie van het materiaalgebruik. De nota van toelichting is op dit punt summier, enkel wordt opgemerkt: 'hiervoor is gekozen omdat de Bepalingsmethode Milieuprestatie Gebouwen en GWWwerken nog niet geschikt is voor toepassing bij verbouw'. ${ }^{69}$ Ook bij de wijziging van het Bouwbesluit 2012, waarbij de milieuprestatiegrenswaarde wordt geïntroduceerd, en in het $\mathrm{Bbl}$ is de milieuprestatiegrenswaarde niet van toepassing verklaard bij de verbouw. ${ }^{70}$ In hoeverre inmiddels al dusdanige stappen zijn gezet dat de Bepalingsmethode Milieuprestatie voldoende geschikt zou kunnen zijn voor toepassing bij verbouw, kan ik las-

65. Eerder in: M.N. Boeve, Het omgevingsrecht van de compacte stad. Het omgevingsrechtelijk instrumentarium voor verdichting en functiemenging in het stedelijk gebied (diss. Amsterdam UvA), 2017, p. 350-351.

66. Zie o.a. N.S.J. Koeman, Het omgevingsplan in de nieuwe Omgevingswet, TO 2016, afl. 4, p. 98-99 en F.A.G. Groothuijse e.a., Omgevingsplan: overgangsrecht, gebodsbepalingen en het verschuiven van onderzoeksplichten, TBR 2016, afl. 8, p. 724-726

67. Zie www.nul20.nl/verwachtingen-solids-komen-niet-uit.

68. Uit art. 4 Woningwet vloeit voort dat het daarbij alleen gaat om die delen van een bouwwerk die daadwerkelijk worden gewijzigd.

69. NvT, Stb. 2011, 676, p. 38.

70. Zie art. 5.4 lid 2 Bbl, waarin is bepaald dat par. 4.4 .2 (milieuprestaties) niet van toepassing is bij verbouwen. tig beoordelen. ${ }^{71} \mathrm{Wel}$ is opvallend dat in de nota van toelichting bij zowel de wijziging van het Bouwbesluit 2012 als het toekomstige $\mathrm{Bbl}$ niet wordt gerept over onderzoek of anderszins beoogde ontwikkelingen op dit punt.

Deze uitzondering op de nieuwbouweisen bij verbouw roept de vraag op wat precies onder 'verbouwen' moet worden verstaan. Is bijvoorbeeld nog sprake van verbouwen als een gebouw wordt gesloopt, maar nog twee muurtjes blijven staan? De tekst van art. 5.10 Bouwbesluit 2012 geeft een ruime omschrijving en ook de nota van toelichting laat zien dat een ruime reikwijdte is beoogd. Zo kan blijkens de toelichting bij geheel vernieuwen 'worden gedacht aan de situatie dat na een calamiteit tot op de fundering gesloopt moet worden en het bouwwerk daarna op diezelfde fundering wordt herbouwd'. ${ }^{72}$ Het laten staan van twee muurtjes als er nog een fundering is, lijkt dus niet nodig om onder de begripsomschrijving van verbouwen te vallen. Het Bouwbesluit 2012 geeft mijns inziens met deze ruime uitzondering weinig vorm aan de circulariteitsambities ten aanzien van de bestaande bouwvoorraad. ${ }^{73}$

Het algemene uitgangspunt van het Bouwbesluit 2012 is overigens dat bij verbouw aan de nieuwbouwvoorschriften moet worden voldaan. In de verschillende hoofdstukken van het Bouwbesluit 2012 zijn telkens specifieke uitzonderingsbepalingen opgenomen waaraan moet worden voldaan bij de verbouw. ${ }^{74}$ Onder het Bouwbesluit 2003 was dit anders, voor afwijking van de nieuwbouweisen moest door burgemeester en wethouders een ontheffing worden gegeven. Deze afhankelijkheid van het bevoegd gezag had volgens Stadig en Minderhoud tot gevolg dat initiatiefnemers steeds over het niveau van de eisen moesten onderhandelen met de gemeente. Gemeenten zetten daarbij in op een zo hoog mogelijk niveau, hetgeen volgens auteurs vertragingen en belemmeringen opleverde bij het transformeren van leegstaande gebouwen. ${ }^{75} \mathrm{Nu}$ duidelijker uit het Bouwbesluit 2012 blijkt welke eisen gelden bij verbouw geeft dit volgens auteurs een impuls aan transformatieprojecten. ${ }^{76}$ Nadeel is wel dat de uitzondering op de nieuwbouweisen voor alle gegeven gevallen geldt en er geen ruimte is voor een individuele toets. Hoewel dit positief blijkt voor het

71. De Bepalingsmethode Milieuprestatie Gebouwen en GWW-werken wordt o.a. ook gehanteerd bij duurzaam inkopen. In dit verband is reeds een rapport verschenen met het oog op het toevoegen van een addendum aan de Bepalingsmethode Milieuprestatie om de methode toepasbaar te maken ten behoeve van 'Duurzaam inkopen van renovatie/transformatie van bestaande kantoorgebouwen', W/E-rapport, Bepaling van de milieuprestatie van te renoveren, of te transformeren, bestaande gebouwen. Addendum op Bepalingsmethode Milieuprestatie Gebouwen en GWW-werken, Utrecht 31 maart 2014.

72. NvT bij Bouwbesluit 2012, par. 6.2.

73. Ten aanzien van energiezuinigheid is wel een aantal voorschriften van toepassing bij verbouw, zie art. 5.6 Bouwbesluit 2012

74. Art. 1.12 Bouwbesluit 2012. Zo behoeft bij verbouw veelal alleen te worden voldaan aan het 'rechtens verkregen niveau' (zie art. 1.1 Bouwbesluit 2012)

75. Stadig \& Minderhoud 2014, par. 1

76. Stadig \& Minderhoud 2014, par. 2. Zie in gelijke zin: H.J. Breeman \& P.H.J. van Aardenne, Transformatie van kantoor naar woningen: welke mogelijkheden biedt het Bouwbesluit?, BR 2011/170, par. 3.1. 
oplossen van de leegstandproblematiek (hetgeen ook te waarderen is vanuit circulariteitsoogpunt), lijkt dit enigszins tegenstrijdig met de wens om in beginsel uit te gaan van een hoog kwaliteitsniveau en bijbehorende eisen. $^{77}$

Ook in het $\mathrm{Bbl}$ is de milieuprestatiegrenswaarde niet van toepassing verklaard bij verbouwen. ${ }^{78}$ De regels voor verbouwen en wijzigen van de gebruiksfunctie zijn in het Bbl opgenomen in een apart hoofdstuk 5. Deze regels zijn uitputtend bedoeld, er is geen ruimte om bij maatwerkregel in het omgevingsplan afwijkende regels te stellen. De milieuprestatiegrenswaarde kan dus ook niet bij maatwerkregel bij verbouw worden voorgeschreven. Een wijziging ten opzichte van het Bouwbesluit 2012 is dat de definitie van verbouwen enigszins is aangepast. Onder 'verbouwen' moet blijkens de begripsbepalingen in bijlage $\mathrm{I}$ bij het $\mathrm{Bbl}$ worden verstaan: 'gedeeltelijk vernieuwen, veranderen of vergroten, anders dan vernieuwen na sloop waarbij alleen de oorspronkelijke fundering resteert'. Als een bouwwerk dus tot op de fundering wordt gesloopt en gevolgd wordt door vervangende nieuwbouw gelden, anders dan onder het Bouwbesluit 2012, wel de nieuwbouwvoorschriften, waaronder de milieuprestatiegrenswaarde. Hier kan overigens wel bij maatwerkvoorschrift van worden afgeweken, waarbij alleen soepelere eisen mogen worden gesteld. ${ }^{79}$

Bij de verbouw van bouwwerken stellen het huidige en toekomstige recht dus weinig eisen aan de milieuprestatie van de toe te passen materialen. Dit is, zeker als sprake is van ingrijpende verbouw, mijns inziens een gemis.

\section{De sloopfase: scheiden van (waardevolle) materialen}

In een circulaire stad zou bij de sloop van bouwwerken de herbruikbaarheid van producten en materialen voorop moeten staan, waardoor de economische waarde van deze materialen blijft behouden. In de visie 'Amsterdam circulair' wordt in dit verband gesproken van een 'slimme sloop'. ${ }^{80}$ Ook wordt in deze context wel de aansprekende term 'urban mining' gehanteerd, waarmee wordt bedoeld dat materialen zoals kozijnen en vloerdelen worden 'geoogst' uit het te slopen bouwwerk om deze weer toe te passen in nieuwe bouwwerken. ${ }^{81}$

77. Hierbij moet wel worden opgemerkt dat in het Bouwbesluit 2003 nog geen eisen aan de milieuprestatie van bouwwerken werden gesteld.

78. Art. 5.4 lid $2 \mathrm{Bbl}$

79. Art. $4.6 \mathrm{Bbl}$.

80. Amsterdam circulair. Een visie en routekaart voor stad en regio, oktober 2015, p. 17.

81. ABN-AMRO, De cirkel is rond. De circulaire toekomst van Nederland, augustus 2017, p. 19 (te raadplegen via insights.abnamro.nl/2017/09/ de-cirkel-is-rond-de-circulaire-toekomst-van-nederland/). En ING, Circular construction. Most opportunities for demolishers and wholesalers, p. 14 (te raadplegen via think.ing.com/reports/circular-construction/).
Zoals in de inleiding al is aangegeven, is in Nederland het recyclingpercentage van bouw- en sloopafval hoog, maar wordt een groot deel van deze materialen laagwaardig toegepast als fundering voor bijvoorbeeld wegen. Om een hogere waarde te behouden is het naast het feit dat in de ontwerpfase van een bouwwerk al rekening zal moeten worden gehouden met de herbruikbaarheid van de materialen, ook van belang dat in de sloopfase de materialen herkenbaar worden gescheiden. In het EU-actieplan voor de circulaire economie wordt dit als een probleem benoemd: 'Waardevolle materialen worden bijvoorbeeld niet altijd herkend, apart ingezameld of adequaat teruggewonnen. ${ }^{82} \mathrm{Om}$ dit te verbeteren ontwikkelt de Europese Commissie onder meer 'specifieke richtsnoeren voor sloopwerkzaamheden, waaronder de behandeling van gevaarlijke afvalstoffen, en bevordert zij systemen voor het sorteren van bouwen sloopafval'. ${ }^{83}$ Ook wordt de nadruk gelegd op de ontwikkeling van 'vrijwillige recyclingsprotocollen'. In 2016 is een 'EU-protocol inzake bouw- en sloopafvalbeheer' gepubliceerd, waarin richtsnoeren worden gegeven om het bouw- en sloopafvalproces te verbeteren en de kwaliteit van gerecyclede bouw- en sloopmaterialen te vergroten. De bedoeling is dat zowel de industrie als de overheid, instellingen voor kwaliteitscertificatie en kopers van gerecyclede bouw- en sloopmaterialen de richtsnoeren in dit protocol toepassen. ${ }^{84}$ Hoewel dit protocol een goede bijdrage kan leveren aan een hoogwaardiger hergebruik en recycling van bouw- en sloopafvalmaterialen, moet wel worden geconstateerd dat het hier een overzicht van maatregelen betreft waarbij vrijwillige toepassing vooropstaat, de richtsnoeren zijn naar hun aard niet juridisch bindend. In het EU-actieplan of elders zijn geen meetbare doelstellingen geformuleerd voor een hoogwaardig hergebruik en recycling van bouw- en sloopmaterialen. Wel is in art. 11 lid 2 onder b van de Kaderrichtlijn afvalstoffen als doelstelling opgenomen om in 2020 het hergebruik, recycling en andere nuttige toepassing van niet-gevaarlijk bouw- en sloopafval te verhogen tot $70 \%$. Deze doelstelling zegt echter niets over de wijze waarop waardevolle materialen moeten worden gerecycled, ook met een laagwaardige toepassing in de fundering van wegen kan aan dit percentage worden voldaan. Backes merkt in dit verband dan ook terecht op:

'(...) these rates concentrate on the wrong parameters. They lead to a concentration on the efforts to the recycling of heavy materials (concrete, brick, etc.), neglecting the question which materials are the most valuable from a circular economy point of view. ${ }^{85}$

Ook Nederland heeft geen gekwantificeerde doelstellingen op dit punt geformuleerd. Wel biedt de nationale

82. EU-actieplan voor een circulaire economie, p. 18

83. EU-actieplan voor een circulaire economie, p. 18

84. Europese Commissie, EU-protocol inzake bouw- en sloopafvalbeheer, 9 september 2016, p. 1-3.

85. Backes 2017, p. 48. 
regelgeving enige randvoorwaarden die kunnen bijdragen aan een betere toepassing van waardevolle materialen afkomstig uit bouw- en sloopafval. Het Bouwbesluit 2012 bevat een regeling inzake het scheiden van bouwen sloopafval. Daarin wordt in algemene zin een 'deugdelijke' scheiding van vrijkomend bouw- en sloopafval voorgeschreven (art. 8.7). Interessanter is dat het Bouwbesluit 2012 erin voorziet dat na een sloopmelding het bevoegd gezag nadere voorwaarden kan opleggen over het scheiden en het op de sloopplaats gescheiden houden van sloopafval in fracties. ${ }^{86}$ Deze bepaling lijkt vooral te zijn bedoeld voor de scheiding van gevaarlijke afvalstoffen die zich in bouw- en sloopafval kunnen bevinden, zoals teerhoudend dakafval. ${ }^{87}$ Deze bepaling lijkt echter niet uit te sluiten om ook voor andere materialen nadere voorwaarden omtrent het scheiden te stellen. Wat overigens precies moet worden verstaan onder het gescheiden houden van sloopafval in 'fracties' is niet duidelijk. ${ }^{88}$ Mijns inziens is niet ondenkbaar dat dit ook grote gebouwdelen kunnen zijn. ${ }^{89}$

In het toekomstige $\mathrm{Bbl}$ is een vergelijkbare regeling opgenomen. Wel is anders dat zowel voor het scheiden van gevaarlijk bouw- en sloopafval als voor 'overig' bouw- en sloopafval is aangegeven in welke 'fracties' het bouw- en sloopafval in ieder geval wordt gescheiden. ${ }^{90}$ In het huidige recht is dit alleen voor het gevaarlijke afval aangegeven. In de nota van toelichting bij het $\mathrm{Bbl}$ wordt bij deze bepaling verwezen naar de afvalhiërarchie zoals opgenomen in de Kaderrichtlijn afvalstoffen, waarbij afvalstoffen zo veel mogelijk moeten worden gerecycled. Dit sluit volgens de toelichting 'ook goed aan bij het streven naar een circulaire economie'. ${ }^{91}$ Een verdere uitwerking of toelichting wordt echter niet gegeven. Net als in het huidige recht kan het bevoegd gezag nadere eisen stellen aan het scheiden en gescheiden houden van het bouw- en sloopafval. Conform de systematiek van de Omgevingswet kan dat in de vorm van zogenoemde maatwerkvoorschriften.

Het huidige en toekomstige recht bieden derhalve wel mogelijkheden voor gemeenten om nadere voorwaarden te stellen aan het scheiden van bouw- en sloopafval, maar het gebruik maken van deze mogelijkheden wordt weinig gestimuleerd, aangezien geen normen zijn

86. Art. 1.29 Bouwbesluit 2012. Een voornemen tot sloop moet ingevolge art. 1.26 Bouwbesluit 2012 worden gemeld als naar redelijke inschatting de te verwachten hoeveelheid sloopafval meer dan $10 \mathrm{~m}_{3}$ zal bedragen, of asbest wordt verwijderd.

87. Zie ook art. 8.9 Bouwbesluit 2012, de NvT, Stb. 2011, 416, p. 346 en art. 4.1 Regeling Bouwbesluit 2012

88. A. Klijn, Circulair bouwen: de Omgevingswet biedt kansen, www. nautadutilh.com/nl/information-centre/nieuws/2017/5/circulairbouwen-de-omgevingswet-biedt-kansen.

89. In art. 4.1 Regeling Bouwbesluit 2012 worden onder meer als fracties benoemd: 'teerhoudende dakbedekking', 'vlakglas al dan niet met kozijn' en armaturen.

90. Art. 7.25 en $7.26 \mathrm{Bbl}$

91. NvT bij Bbl, p. 310. Dit is overigens opvallend genoeg de enige verwijzing in de NvT van het Bbl naar de ambities om een circulaire economie te bereiken. gesteld voor een hoogwaardig hergebruik of recycling van bouw- en sloopafval.

\section{Conclusie}

Het thema 'bouwen' is een belangrijk onderwerp bij het bereiken van de doelstelling om in 2050 volledig circulaire steden te realiseren. Hoewel voor circulair bouwen (vrijwillige) initiatieven vanuit de markt een belangrijke aanjager zullen zijn, zal regelgeving als stok achter de deur ook een stimulans kunnen en moeten bieden om de overgang naar een circulaire economie tijdig te bereiken. Voor nieuwbouw biedt vooral het toekomstige Bbl kansen voor een ambitieuzere normstelling op gemeentelijk niveau ten aanzien van verantwoord materiaalgebruik door middel van het stellen van maatwerkregels. Daarbij plaats ik de kanttekening dat een motivering van dergelijke locatieonafhankelijke regels in het omgevingsplan niet altijd eenvoudig zal zijn, waarbij ook van belang is dat rechtsbescherming openstaat tegen de maatwerkregels in het omgevingsplan. Mijns inziens ligt een aanscherping van deze normstelling op nationaal niveau meer voor de hand. Het huidige Bouwbesluit 2012 laat ten aanzien van de circulariteit van bouwmaterialen bij nieuwbouw maar weinig stimulansen zien, aangezien enkel het berekenen van de milieuprestatie van nieuw te bouwen bouwwerken is voorgeschreven. Ten aanzien van de bestaande bouw moet worden geconcludeerd dat bij verbouwen geen eisen kunnen worden gesteld aan de milieuprestatie van de toe te passen materialen, ook niet in het toekomstige recht. Zeker gelet op de ruime omschrijving van 'verbouwen' biedt dit weinig kansen of stimulansen voor circulair bouwen. Of het omgevingsrecht voldoende kansen biedt om een lange levensduur van gebouwen te bereiken door een eenvoudige functiewijziging in het bestemmingsplan of omgevingsplan mogelijk te maken, is de vraag. Een geheel 'bestemmingsloos' gebouw is juridisch niet houdbaar vanuit een oogpunt van een aanvaardbaar woon- en leefklimaat. Of de beoogde 'globale' omgevingsplannen onder de Omgevingswet op dit punt een bijdrage kunnen leveren, is nog maar de vraag. Ook een globaal plan zal immers een zekere mate van duidelijkheid moeten bieden om de aanvaardbaarheid van het plan te kunnen beoordelen. Tot slot kan worden geconcludeerd dat het Bouwbesluit 2012 en het $\mathrm{Bbl}$ ruimte bieden om nadere voorwaarden te stellen aan scheiding van het bouw- en sloopafval. Of deze mogelijkheden in de praktijk ook worden benut, zal afhangen van de ambities van de desbetreffende gemeente. Deze ambitie wordt weinig gestimuleerd, ook gelet op het feit dat er zoals gezegd geen gekwantificeerde normen zijn ten aanzien van een hoogmaardig hergebruik of recycling van bouw- en sloopafval.

Het huidige en toekomstige omgevingsrecht bevatten kansen voor een overgang naar circulair bouwen, maar bieden op de onderzochte onderwerpen al met al weinig stimulansen. Het instrumentarium kan daarmee onvoldoende dienen als 'stok achter de deur', waarmee het 
risico bestaat dat buiten de 'koplopers' het circulair bouwen maar weinig van de grond komt. 